\section{Acute kidney injury in Colombian patients with COVID-19 who received kidney support therapy with genius ${ }^{\circledR}$ 90 technology}

\author{
Emilio Rey-Vela ${ }^{1}$, Jesús Muñoz ${ }^{2}$, Jorge Rico-Fontalvo², \\ Rodrigo Daza-Arnedo ${ }^{2}$, Katherin Portela-Buelvas ${ }^{3}$, Nehomar \\ Pájaro-Galvis $^{4 *}$, Víctor Leal-Martínez ${ }^{5}$, Emilio Abuabara- \\ Franco ${ }^{6}$, José Cabrales-Juan 7 , Leonardo Marín' ${ }^{2}$, Lucas Daza ${ }^{2}$, \\ Samuel Cuadro², Emir Ortiz², María Raad-Sarabia ${ }^{4}$, \\ Cesar Ferrer ${ }^{2}$, Alejandra Prada ${ }^{2}$, Greisy González², Elkin \\ Mendoza' ${ }^{2}$, Klearly Tinoco' ${ }^{2}$, Jorge Camacho ${ }^{2}$, Joel Ortega ${ }^{2}$, \\ Carlos Tobón ${ }^{8}$, Juan Montes ${ }^{9}$, Jorge Coronado ${ }^{2}$, Luis Salgado- \\ Montiel $^{10}$, José Correa ${ }^{12}$, Fabio Salas ${ }^{11}$, Amilkar Almanza- \\ Hurtado ${ }^{13}$ and Miguel Aguilar-Schorborg ${ }^{14}$
}

\footnotetext{
${ }^{1}$ Cardiovascular Anesthesiologist, Intensivist, Fresenius Medical Care, Colombia

${ }^{2}$ Nephrologist, Fresenius Medical Care, Colombia

${ }^{3}$ Epidemiologist, Clínica Antioquia, Medellín, Colombia

${ }^{4}$ Resident Physician, Department of Internal Medicine, Universidad del Sinú, Cartagena, Colombia

${ }^{5}$ Internist, Nuevo Hospital Bocagrande, Cartagena, Colombia

${ }^{6}$ Internist, Clínica Estrios, Cartagena, Colombia

${ }^{7}$ Resident Physician, Department of Internal Medicine, St. Elizabeth's Medical Center/Tufts

University School of Medicine, Boston, MA, USA

${ }^{8}$ Epidemiologist , Fresenius Medical Care, Colombia

IIntensivist, Hospital Universitario del Caribe, Cartagena, Colombia

${ }^{10}$ Physician, Nuevo Hospital Bocagrande, Cartagena, Colombia

${ }^{11}$ Internist, Clínica Jesús de Nazareth, Cartagena, Colombia

${ }^{12}$ Internist, Critical Care Fellow, Universidad de Cartagena, Cartagena, Colombia

${ }^{13}$ Internist, Clínica Gestión Salud, Cartagena, Colombia

${ }^{14}$ Physician, Clínica Gestión Salud, Cartagena, Colombia
}

\section{More Information}

*Address for Correspondence: Nehomar Pajaro-Galvis, Third year Resident Physician, Department of Internal Medicine, University of Sinu, Colombia,

Tel: $57+3008233570$;

Email: neho94@hotmail.com

Submitted: 14 August 2020

Approved: 09 September 2020

Published: 11 September 2020

How to cite this article: Rey-Vela E, Muñoz J, Rico-Fontalvo J, Daza-Arnedo R, Portela-Buelvas K, Pájaro-Galvis N. et al. Acute kidney injury in Colombian patients with COVID-19 who received kidney support therapy with genius ${ }^{\otimes} 90$ technology. J Clini Nephrol. 2020; 4: 056-060.

DOI: 10.29328/journal.jcn.1001059

Copyright: @ 2020 Rey-Vela E, et al. This is an open access article distributed under the Creative Commons Attribution License, which permits unrestricted use, distribution, and reproduction in any medium, provided the original work is properly cited.

Keywords: Coronavirus; Acute kidney injury; Renal replacement therapy

(T) Check for updates
(5) OPEN ACCESS

\title{
Abstract
}

Introduction: Acute kidney injury (AKI) is one of the complications associated with severe COVID-19 infection, and it can present in up to $20 \%$ to $40 \%$ of the cases; of these, approximately $20 \%$ will require renal replacement therapy (RRT).

Objective: To establish clinical and laboratory characteristics in a group of patients from Colombia with COVID-19 infection and AKI that received intermittent and prolonged RRT with the GENIUS ${ }^{\circledR} 90$ technology in between March and July 2020.

Design: Cross-sectional study.

Results: $78.9 \%$ of participants were men and $21.1 \%$ were women. The main comorbidities were the following: Hypertension (65.3\%), diabetes mellitus (38.9\%), obesity (26.3\%), cancer (5.3\%), Chronic obstructive pulmonary disease (11.6\%), cardiovascular disease (23.2\%), active smoking (11.6\%). 33.7\% had chronic kidney disease (CKD) in the average serum creatinine on admission was $4.4 \mathrm{mg} / \mathrm{dl}$.

The following inflammatory markers were elevated: C-reactive protein (CRP), d-dimer and ferritin (20.3 mg/dl, $931 \mathrm{mcg} / \mathrm{l}$ and $1174 \mathrm{ng} / \mathrm{ml}$, respectively). $63.5 \%$ of patients underwent sustained low-efficiency dialysis (SLED) (6 to 12 hours) and the rest of the patients (36.35\%) underwent conventional hemodialysis (less than 4 hours). The mortality of the total patient sample was $36.9 \%$, lower in patients with CKD than in patients with no previous renal disease history ( $18.7 \%$ and $40.1 \%$, respectively).

Conclusion: Renal complications are frequent in patients with severe COVID-19. The development of AKI could be an isolated prognostic marker associated with an increase in mortality in patients with COVID-19, and one of the options is intermittent and prolonged RRT with the GENIUS ${ }^{\circledR} 90$ system. 


\section{Introduction}

COVID-19 is an infectious disease caused by the new coronavirus SARS-CoV-2, a virus that is highly related to SARS-CoV, which caused an epidemic in the year 2002. Since the first reported cases in December 2019, there has been exponential increase in its numbers, and currently there exists a high number of cases of people infected with COVID-19, which is associated with a high percentage of morbidity and mortality.

Acute kidney injury is a condition in which a rapid deterioration of the kidney function occurs, with electrolyte disturbances, acid-base disturbances, a decrease in urine output and an accumulation of nitrogen waste products [1], it is one of the complications associated with COVID-19 infection and in a high number of cases it requires renal replacement therapy. There are several options of treatment including: Continuous renal replacement therapy, conventional hemodialysis, and prolonged intermittent therapies.

Prolonged hemodialysis consists in ultrafiltration which is almost exclusive in its diffusion mechanism [2]. It is a technique with high efficacy that utilizes low blood flow and a low dialysate, which has been established as a substitute for continuous renal replacement therapy in critically ill patients with hemodynamic instability. It has also been established as a transition therapy from continuous renal replacement therapy to intermittent hemodialysis [3,4]. It is safe and costeffective, being a good option for patients with COVID-19. However, there are no published studies about the use of these therapies in patients with COVID-19 and AKI.

\section{Materials and methods}

This is a cross-sectional study held in a group of patients from Colombia with the diagnosis of COVID-19 and AKI that received PIRRT in between March and July 2020 in the cities of Bogotá, Cartagena, Barranquilla, Valledupar, Bucaramanga, Pereira, Ibague, Cali and Medellin.

Inclusion criteria: Patient is above 18 years of age, positive COVID-19 results by reverse transcriptase polymerase chain reaction (RT-PCR) or antibodies against SARS-CoV-2, acute kidney injury requiring conventional hemodialysis and prolonged therapies with the GENIUS ${ }^{\circledR} 90$ technology. A nonprobabilistic sampling was used by convenience for patients that met the inclusion criteria.

Exclusion criteria: Patient with end-stage kidney disease on previous renal replacement therapy.

The data was obtained from secondary sources, by medical chart reviewing of patients with COVID-19 and acute kidney injury requiring renal replacement therapy at Fresenius medical care- FM express program in nine cities of Colombia, between March and July of the year 2020.
The analysis was made via the STATA 13 statistical program, a license of Fresenius Medical Care Colombia. The qualitative variables were expressed and absolute and relative frequency (\%). The normal distribution of the data was evaluated for the quantitative variables with Kolmogorov-smirnov test, and based on the findings, were expressed in mean, with a standard deviation or median with interquartile range, with confidence intervals of $95 \%$. Sex distribution and prevalence of diabetes, hypertension, obesity, COPD, active smoking, cardiovascular disease, cancer and CKD were established. The prevalence of the COVID-19 diagnostic method, the presence of proteinuria and hematuria in the urinalysis, the initiation of RRT, intensive care unit admission, mechanical ventilation, vasopressor requirement, extra-corporeal membrane circulation (ECMO) and mortality were calculated.

Additionally, the strength of the association between the clinical characteristics and laboratory parameters of the patients with the mortality was measured via Odds ratio (OR), with $95 \%$ confidence interval, with a $p$ value of $<0.05$ indicating statistical significance.

\section{Results}

A total of 117 patients were selected, 22 of them had clinical charts that were incomplete, reason why 95 patients were included in the analysis.

Of all participants, $78.9 \%$ were male and $21.1 \%$ were female; the median age was 64 years; of all patients, $65.3 \%$ had hypertension, $38.9 \%$ were diabetic, $26.3 \%$ were obese, $5.3 \%$ were cancer patients, $11.6 \%$ had COPD, $23.2 \%$ had cardiovascular disease and $11.6 \%$ were active smokers.

CKD was found in $33.7 \%$. The rest of the patients, $66.3 \%$ did not have previous chronic kidney disease. During the evaluation of clinical and socio-demographic characteristics of the patients, it was identified that those with chronic disease were older than patients without CKD. However, this was not statistically significant, as the $p$ value was $>0.05$. Table 1.

In the group with CKD, $84.4 \%$ had hypertension, 53.1\% had type 2 diabetes mellitus, and $23.2 \%$ of patients had cardiovascular disease. In the group without CKD, 55.6\% of the participants had hypertension, $31.7 \%$ had type 2 diabetes, and $9.5 \%$ had cardiovascular disease, with a statistically significant difference (Table 1).

On the other hand, several labs previous to the initiation of RRT were considered, identifying a median of creatinine of 4.4 (5.92-3.30) mg/dl, a median of CRP of 20.3 (5.92-3.30) $\mathrm{ng} / \mathrm{ml}$ and d-dimer of 931 (2200-140) $\mathrm{mcg} / \mathrm{L}$ without a statistically significant difference between patients with and without CKD. However, the median of hemoglobin in people with CKD was 9.9 (11.35-8.5) g/dl, being lower in the group 
without the disease, 11.0 (12.0-9.3), with a $p$ value of less than 0.05 (Table 2).

In our study, of all the patients, only 13 had procalcitonin measurements with a median of 4.2 (5.6-1.6) $\mathrm{ng} / \mathrm{ml}$, and 57 participants with ferritin reports, with a median of 1174 (1650-884) ng/ml. Additionally, on evaluation of the RRT given to patients, the median number of SLED sessions was $5.0(9.0-1.0)$, while the median number of sessions for regular hemodialysis was 3 (4.0-1.0).

In general, the patients in the study were critically ill. Of all participants, $86.3 \%$ required intensive care unit level of care. Of these, $31.7 \%$ had CKD and $68.3 \%$ did not have the disease. The majority of patients required mechanical ventilation and around two thirds of the patient's required at least one vasopressor. Additionally, when comparing the SOFA and APACHE scores on admission to the ICU amongst participants, the median of APACHE was 16.5 (22-9) points and the median of SOFA was 8 (11.7-4.0) for patients with
CKD, while in patients without it. The median of APACHE and SOFA scores were 16 (21-0) and 8 (12-3) points, respectively, without a statistically significant difference $(p>0.05)$ (Table 3$)$.

Finally, a mortality of $36.9 \%$ was identified in the total number of participants, with less mortality in patients with CKD, 6/32 (18.7\%) in comparison to the patients without CKD, 29/63 (40.1\%), with a statistically significant difference (Table 3).

\section{Discussion}

COVID-19 is infectious disease caused by RNA monocatenary virus SARS-CoV-2, which is not only a local pulmonary infection, but compromises multiple systems that can lead to multiple organ system dysfunction, given a dysregulated inflammatory response. The latter due to the action of the virus itself in the epithelial cells [1-4]. The virus attaches to the carbopeptidase receptor related to the angiotensin-converting enzyme 2 (ACE-2), found in

\begin{tabular}{|c|c|c|c|c|}
\hline Variable & Total $(n=95)$ & CKD $32(33,7 \%)$ & No CKD $63(66,3 \%)$ & $p$ value \\
\hline Age, Me [IQR] & $64,0[71,0-56,0]$ & $67,5[71,0-61,0]$ & $62,0[72,0-54,0]$ & 0,238 \\
\hline $\begin{array}{l}\text { Gender, } n(\%) \\
\text { Female } \\
\text { Male }\end{array}$ & $\begin{array}{l}20(21,1) \\
75(78,9)\end{array}$ & $\begin{array}{c}9(28,1) \\
23(71,9)\end{array}$ & $\begin{array}{l}11(17,5) \\
52(82,5)\end{array}$ & 0,228 \\
\hline $\begin{array}{l}\text { Hypertension, } n(\%) \\
\text { Yes } \\
\text { No }\end{array}$ & $\begin{array}{l}62(65,3) \\
33(34,7)\end{array}$ & $\begin{array}{c}27(84,4) \\
5(15,6)\end{array}$ & $\begin{array}{l}35(55,6) \\
28(44,4)\end{array}$ & $0,005^{*}$ \\
\hline $\begin{array}{c}\text { Type } 2 \text { Diabetes Mellitus, } n(\%) \\
\text { Yes } \\
\text { No }\end{array}$ & $\begin{array}{l}37(38,9) \\
58(61,1)\end{array}$ & $\begin{array}{l}17(53,1) \\
15(46,9)\end{array}$ & $\begin{array}{l}20(31,7) \\
43(68,3)\end{array}$ & $0,043^{*}$ \\
\hline $\begin{array}{c}\text { Obesity, } n(\%) \\
\text { Yes } \\
\text { No }\end{array}$ & $\begin{array}{l}25(26,3) \\
70(73,7)\end{array}$ & $\begin{array}{c}5(15,6) \\
37(84,4)\end{array}$ & $\begin{array}{l}20(31,7) \\
43(68,3)\end{array}$ & 0,092 \\
\hline $\begin{array}{l}\text { Cancer, } n(\%) \\
\text { Yes } \\
\text { No }\end{array}$ & $\begin{array}{c}5(5,3) \\
90(94,7)\end{array}$ & $\begin{array}{c}1(3,1) \\
31(96,9)\end{array}$ & $\begin{array}{c}4(6,3) \\
59(93,7)\end{array}$ & 0,506 \\
\hline $\begin{array}{c}\text { COPD, } n(\%) \\
\text { Yes } \\
\text { No }\end{array}$ & $\begin{array}{l}11(11,6) \\
84(88,4)\end{array}$ & $\begin{array}{c}4(12,5) \\
28(87,5)\end{array}$ & $\begin{array}{c}7(11,1) \\
56(88,9)\end{array}$ & 0,842 \\
\hline $\begin{array}{c}\text { Cardiovascular disease, } n(\%) \\
\text { Yes } \\
\text { No }\end{array}$ & $\begin{array}{l}22(23,2) \\
73(76,8)\end{array}$ & $\begin{array}{l}16(50,0) \\
16(50,0)\end{array}$ & $\begin{array}{c}6(9,5) \\
57(90,5)\end{array}$ & $<0,001^{*}$ \\
\hline $\begin{array}{c}\text { Active Smoking, } n(\%) \\
\text { Yes } \\
\text { No }\end{array}$ & $\begin{array}{l}11(11,6) \\
84(88,4)\end{array}$ & $\begin{array}{c}4(12,5) \\
28(87,5)\end{array}$ & $\begin{array}{c}7(11,1) \\
56(89,9)\end{array}$ & 0,918 \\
\hline
\end{tabular}

Table 2: Laboratory characteristics of patients initiating RRT.

\begin{tabular}{|c|c|c|c|c|}
\hline Variable & Total $(n=95)$ & CKD $32(33,7 \%)$ & No CKD $63(66,3 \%)$ & $p$ value \\
\hline Creatinine mg/dl, Me [IQR] & $4,40[5,92-3,30]$ & $5,39[7,48-3,46]$ & $4,31[5,70-3,15]$ & 0,084 \\
\hline \multicolumn{5}{|c|}{ Inflammatory Markers } \\
\hline CRP mg/dl, Me [IQR] & $20,30[41,60-7,60]$ & $23,2[118,2-8,90]$ & $16,0[37,8-4,70]$ & 0,547 \\
\hline D-Dimer $\mu \mathrm{g} / \mathrm{l}, \mathrm{Me}$ [IQR] & $931,0[2200,0-140,0]$ & $1139,0[2076,5-398,7]$ & $783,3[3380,0-0]$ & 0,492 \\
\hline \multicolumn{5}{|c|}{ Complete Blood Count } \\
\hline Hemoglobin g /dl, Me [IQR] & $10,70[12,00-9,10]$ & $9,90[11,35-8,50]$ & $11,0[12,0-9,30]$ & $0,035^{*}$ \\
\hline \multicolumn{5}{|c|}{ Acid Base Status and Electrolytes } \\
\hline $\mathrm{pH}, \mathrm{Me}[\mathrm{IQR}]$ & $7,29[7,37-7,17]$ & $7,31[7,38-7,24]$ & $7,28[7,34-7,16]$ & 0,235 \\
\hline $\mathrm{HCO} 3, \mathrm{mmol} / \mathrm{l}, \mathrm{Me}[\mathrm{IQR}]$ & $18,00[21,2-14,2]$ & $18,1[20,9-15,4]$ & $18,0[21,3-13,7]$ & 0,923 \\
\hline Lactate $\mathrm{mmol} / \mathrm{l}, \mathrm{Me}$ [IQR] & $1,93[2,73-1,40]$ & $1,80[2,72-1,28]$ & $2,00[2,73-1,40]$ & 0,381 \\
\hline $\mathrm{PaO} 2 / \mathrm{FiO} 2, \mathrm{Me}[\mathrm{IQR}]$ & $148,0[205,0-78,0]$ & $173,5[224,5-101,5]$ & $123,0[190,0-71,0]$ & 0,053 \\
\hline Sodium, mEq/l, Me [IQR] & $138,0[141,0-133,0]$ & $137,5[141,0-133,2]$ & $138,0[142,0-133,0]$ & 0,374 \\
\hline Potassium, mEq/l, Me [IQR] & $4,90[5,80-4,00]$ & $4,85[5,77-4,00]$ & $5,00[5,80-4,00]$ & 0,812 \\
\hline
\end{tabular}


Table 3: Characteristics of patients in the intensive care unit (ICU).

\begin{tabular}{|c|c|c|c|c|}
\hline Variable & Total $(n=95)$ & CKD $32(33,7 \%)$ & No CKD 63 (66,3\%) & $p$ value \\
\hline $\begin{array}{c}\text { ICU level of care requirement, } n(\%) \\
\text { Yes } \\
\text { No }\end{array}$ & $\begin{array}{l}82(86,3) \\
13(13,7)\end{array}$ & $\begin{array}{c}26(81,3) \\
6(18,7)\end{array}$ & $\begin{array}{c}56(88,8) \\
7(11,1)\end{array}$ & 0,068 \\
\hline $\begin{array}{c}\text { Mechanical Ventilation, } n(\%) \\
\text { Yes } \\
\text { No }\end{array}$ & $\begin{array}{c}80(97,5) \\
2(2,5)\end{array}$ & $\begin{array}{c}25(96,1) \\
1(3,9)\end{array}$ & $\begin{array}{c}55(98,2) \\
1(1,8)\end{array}$ & 0,951 \\
\hline $\begin{array}{l}\text { Use of at least one vasopressor, } n(\%) \\
\text { Yes } \\
\text { No }\end{array}$ & $\begin{array}{l}70(85,3) \\
12(14,7)\end{array}$ & $\begin{array}{l}22(68,7) \\
10(31,3)\end{array}$ & $\begin{array}{l}48(76,1) \\
15(26,8)\end{array}$ & 0,324 \\
\hline SOFA score on ICU admission, Me [IQR] & $8,00[12,00-3,00]$ & $8,00[11,7-4,00]$ & $8,00[12,0-3,00]$ & 0,366 \\
\hline APACHE score on ICU admission, Me [IQR] & $16,00[21,0-0]$ & $16,5[22,0-9,00]$ & $16,0[21,0-0]$ & 0,374 \\
\hline $\begin{array}{c}\text { Patient's final status, } \mathrm{n}(\%) \\
\text { Alive } \\
\text { Deceased }\end{array}$ & $\begin{array}{l}60(63,1) \\
35(36,9)\end{array}$ & $\begin{array}{c}26(81,3) \\
6(18,7)\end{array}$ & $\begin{array}{c}34(53,9) \\
29(40,1)\end{array}$ & $0,009^{*}$ \\
\hline
\end{tabular}

cardiopulmonary tissue, kidneys and the immune system cells. In this way, it can cause infection of the glomeruli and the renal tubular epithelium [5]. AKI is common in patients with COVID-19, being present in approximately 20 to $40 \%$ of the patients admitted to the ICU. Of these, $20 \%$ require RRT during the course $[3,8]$.

The mechanisms behind kidney damage are unclear and likely multifactorial in origin. There are several potential mechanisms of kidney injury in COVID-19 infection; cytokine damage is one of the proposed mechanisms, with a direct toxic effect of the cytokines on the renal tubules. Other mechanisms include organ crosstalk, for example, if patients develop cardiomyopathy and consequently cardiorenal syndrome, or alveolar damage leading to medullary hypoxia [6]. Systemic effects such as hypotension, positive fluid balance and rhabdomyolysis may also lead to acute kidney injury [6]. In a study of 26 autopsies with patients with COVID-19, diffuse erythrocyte aggregation with endothelial damage and obstruction were found in the peritubular and glomerular capillaries [7]. There was also diffuse damage of the proximal tubules with loss of the brush border, vacuolar degeneration and necrosis. It is also thought that kidney disease may be caused by SARS-CoV-2 entering the kidney cells via the ACE- 2 receptor, and can cause damage by inducing tubular damage via deposition of MAC complexes on tubules and infiltration CD68+ macrophages in the tubuleinterstitium [7].

In our study we found that the median of age of patients with AKI secondary to COVID-19 was similar to other published studies such as Hirsch, et al. and Chan, et al. $[9,10]$. However, a meta-analysis published recently composed primarily of Chinese patients showed a great variability in the age, including patients from 47 to 70 years old [11].

In the Spanish register acute kidney failure COVID-19 [12], it was found that more than $60 \%$ of the patients were hypertensive, around $30 \%$ of the patients were diabetic, $32 \%$ were obese, 14\% had COPD and less than 10\% were cancer patients.

While it is true that CKD is a major risk factor for AKI, as shown by Hirsch, et al. [10], the majority of our patients did not have CKD at baseline, suggesting that even though kidney function is preserved, patients are still at risk of developing AKI.

The median of creatinine on admission in our study differs from the one reported in other studies $[9,10]$. This is due to the fact that the serum creatinine obtained in our study was previous to the start of RRT; additionally, our data came from medical charts, not having the baseline serum creatinine previous to hospitalization.

The average level of d-dimer and CRP were both high in all the patients as expected in COVID-19 infection, even higher than in other published studies like Richardson, et al. in the United states of America [11], were the mean CRP value was $13 \mathrm{mg} / \mathrm{dl}$ and d-dimer was $438 \mathrm{mcg} / \mathrm{L}$. Of the total of our patients, the procalcitonin and ferritin levels were higher in comparison with the values in the study published by Richardson, et al. [11].

The average blood gas analysis in our study showed metabolic acidosis and moderate hypoxemia, which reflects in the severity of COVID 19 infection in the participants. Of the total sample, a high number of patients required ICU level of care, and of these, more than ninety-percent required mechanical ventilation and the majority required vasopressors. These findings are higher than the ones reported in Rubin, et al. were $77 \%$ of the patients' required mechanical ventilation and the mean SOFA score was 6 .

Global mortality in our patients was $36.9 \%$, similar to other studies such as Hirsch et al, were the mortality was $34.8 \%$ [8]. It is worth to highlight that the mortality was lower in patients with CKD than in patients without CKD. Within the analysis of this study a hypothesis is generated, that the natural immunosuppressive state in CKD patients may protect against the cytokine storm by COVID-19 [13-15], that is present in patients that are previously healthy without any immunosuppression. However, randomized clinical trials have to be made to corroborate the latter, given that for now, only studies with descriptive methodology have been published. 
One of the strengths in our study is that even though there is data published regarding AKI in COVID-19 patients. This is the first study to not only include patients with AKI and confirmed or highly probably COVID-19, but also with intermittent or prolonged RRT with the GENIUS ${ }^{\circledR} 90$ technology. Additionally, patients from several cities of Colombia were included, which labels it as a multicenter study for extrapolation of the results.

Its main limitation is that it's a cross sectional study, which makes it impossible to appreciate the impact of our RRT through time. Furthermore, a small percentage of the patients included have a negative COVID-19 RT-PCR, but with high clinical suspicion and positive serology (probable cases). Finally, there was no information obtained in regards to urine output and the baseline creatinine, which did not allow the classification of AKI by severity.

\section{Conclusion}

Renal complications are frequent in patients with severe COVID-19 and its clinical presentation is variable, including hematuria, proteinuria and acute kidney injury requiring RRT. The development of AKI could be an isolated prognostic marker associated with an increase in mortality in patients with COVID-19, and one of the options is intermittent and prolonged RRT with the GENIUS ${ }^{\circledR} 90$ system. The GENIUS ${ }^{\circledR}$ 90 technology is available in Colombia over 10 years ago and is operated by FM express program of Fresenius Medical Care Colombia, and through this study, we aimed to characterize Colombian patients with AKI by COVID-19 that received intermittent and prolonged RRT.

\section{References}

1. Yuki K, Fujiogi M, Koutsogiannaki S. COVID-19 pathophysiology: A review. Clin Immunol. 2020 215: 108427. https://linkinghub.elsevier.com/retrieve/pii/S152166162030262X

2. Sinha P, Matthay MA, Calfee CS. Is a "Cytokine Storm" Relevant to COVID-19? JAMA Intern Med. 2020. https://jamanetwork.com/ journals/jamainternalmedicine/fullarticle/2767939

3. Ronco C, Reis T, Husain-Syed F. Management of acute kidney injury in patients with COVID-19. The Lancet Respiratory Medicine. 2020; 8: 738-742.

https://linkinghub.elsevier.com/retrieve/pii/S2213260020302290

4. Robba C, Battaglini D, Pelosi P, Rocco PRM. Multiple organ dysfunction in SARS-CoV-2: MODS-CoV-2. Expert Review of Respiratory Medicine. 2020; 1-4.

https://www.tandfonline.com/doi/full/10.1080/17476348.2020.1778470
5. Daza Arnedo R, Aroca Martínez G, Rico Fontalvo JE, Rey Vela E, Pájaro Galvis NE, et al. Terapias de purificación sanguínea en COVID-19. Rev Colomb Nefrol. 2020; 7: 33-34. https://revistanefrologia.org/index.php/rcn/article/view/476

6. Ronco C, Reis T. Kidney involvement in COVID-19 and rationale for extracorporeal therapies. Nat Rev Nephrol. 2020; 16: 308-310.

7. Benedetti C, Waldman M, Zaza G, Riella L, Cravedi P. COVID-19 and the kidneys: An Update. Front. Med. 2020.

8. Gonzalez C, Yama E, Yomayusa N, Vargas J, Rico J, et al. Consenso colombiano de expertos sobre recomendaciones informadas en la evidencia para la prevención, diagnóstico y manejo de la lesión renal aguda por SARS-CoV-2/COVID-19. Rev Colomb Nefrol 2020; 7(Supl2). https://revistanefrologia.org/index.php/rcn/article/view/473

9. Chan L, Chaudhary K, Saha A, Chauhan K, Vaid A, et al. Acute Kidney Injury in Hospitalized Patients with COVID-19 [Internet]. Nephrology. 2020. http://medrxiv.org/lookup/doi/10.1101/2020.05.04.20090944

10. Hirsch JS, Ng JH, Ross DW, Sharma P, Shah HH, et al. Acute kidney injury in patients hospitalized with COVID-19. Kidney International. 2020; 98: 209-218.

https://linkinghub.elsevier.com/retrieve/pii/S0085253820305329

11. Ng JJ, Luo Y, Phua K, Choong AMTL. Acute kidney injury in hospitalized patients with coronavirus disease 2019 (COVID-19): A meta-analysis. J Infect. 2020; S0163445320302802. https://linkinghub.elsevier.com/retrieve/pii/S0163445320302802

12. Maria Dolores del Pino. REGISTRO FRACASO RENAL AGUDO COVID-19 Informe 1. Sociedad Española de Nefrología. 2020.: https://us10.campaign-archive.com/?u=758507e42a1311e40debf34 ad\&id $=a 177 \mathrm{db} 805 \mathrm{~b}$

13. Richardson S, Hirsch JS, Narasimhan M, Crawford JM, et al. Presenting Characteristics, Comorbidities, and Outcomes Among 5700 Patients Hospitalized With COVID-19 in the New York City Area. JAMA. 2020; 323: 2052. https://jamanetwork.com/journals/jama/fullarticle/2765184

14. Rubin S, Orieux A, Prevel R, Garric A, Bats ML, et al. Characterization of acute kidney injury in critically ill patients with severe coronavirus disease 2019. Clin Kidney J. 2020; sfaa099. https://academic.oup. com/ckj/advance-article/doi/10.1093/ckj/sfaa099/5854260

15. Pahl MV, Vaziri ND. Immune Function in Chronic Kidney Disease. En: Chronic Renal Disease. Elsevier. 2015; 285-297. https://linkinghub.elsevier.com/retrieve/pii/B978012411602300024X

16. Kato S, Chmielewski M, Honda H, Pecoits-Filho R, Matsuo S, et al. Aspects of Immune Dysfunction in End-stage Renal Disease. CJASN. 2020; 3: 1526-1533. http://cjasn.asnjournals.org/lookup/doi/10.2215/CJN.00950208

17. Lamarche C, lliuta IA, Kitzler T. Infectious Disease Risk in Dialysis Patients: A Transdisciplinary Approach. Can J Kidney Health Dis. 2020; 6: 205435811983908 http://journals.sagepub.com/doi/10.1177/2054358119839080

18. Ronco C, Reis T. Kidney involvement in COVID-19 and rationale for extracorporeal therapies. Nat Rev Nephrol. 2020; 16: 308-310.

19. Benedetti C, Waldman M, Zaza G, Riella L, Cravedi, P. COVID-19 and the kidneys: An Update. Front Med. 2020. 